\title{
Effectiveness of Caudal Epidural Injections in Discogram Positive and Negative Chronic Low Back Pain
}

\author{
Laxmaiah Manchikanti, MD*, Vijay Singh, MD\#, Jose J. Rivera, MD, Vidyasagar Pampati, MSc*, \\ Carla Beyer, RN"\#, Kim Damron, RN"\#, and Renee C. Barnhill, RN"\#
}

Epidural steroid injections are the most commonly used procedures to manage chronic low back pain in interventional pain management settings. The overall effectiveness of epidural steroid injections has been highly variable, and in the role has not been evaluated in patients discographically evaluated. One hundred consecutive patients, without evidence of disc herniation or radiculitis, who had failed to respond to conservative management with physical therapy, chiropractic and/or medical therapy, underwent discography utilizing strict criteria of concordant pain, and negative adjacent discs, after being judged to be negative for facet joint and/or sacroiliac joint pain utilizing comparative local anesthetic blocks. Any other type of response was considerednegative.

This study included 62 patients, who underwent caudal epidural steroid injections with Sarapin ®. They included Group I, comprised of 45 of 55 patients negative on provocative discography; and Group II, with 17 of 45 patients with positive provocative discography.

Results showed that there was significant improvement in patients receiving caudal epidural injections, with a decrease in pain associated with improved physical, functional, and mental status; decreased narcotic intake, and increased return to work. The study showed that at 1 month, $100 \%$ of the patients evaluated showed significant improvement in both groups; this declined to $86 \%$ at 3 months in Group I, but remained at $100 \%$ in Group II, declining to $60 \%$ and $64 \%$ at 6 months in Group I and Group II, respectfully, with administration of one to three injections. Analysis with one to three injections, which included all (62) patients showed significant relief in $71 \%$ and $65 \%$ of the patients at 1 month, in $67 \%$ and $65 \%$ at 3 months, and in $47 \%$ and $41 \%$ at 6 months, in Group I and Group II, respectively.

In conclusion, caudal epidural injections with or without steroids is an effective modality of treatment in managing chronic, persistent low back pain failing to respond to conservative modalities of treatments, in patients negative for facet joint and sacroiliac joint pain, whether positive or negative, on evaluation with provocative discography.

Keywords: Discogenic pain, provocative discography, chronic low back pain, caudal epidural injections, betamethasone, methylprednisolone, Sarapin
Chronic low back pain is the most frequent and persistent pain, with frequent or persistent pain being estimated in around $15 \%$ of the US population, and a lifetime prevalence of $65 \%$ to $80 \%(1,2)$. It also has been reported that $13 \%$ of the population suffers with persistent low back pain of high intentsity, with either moderate or severe disability

From Pain Management Center of Paducah, Paducah, Kentucky and Pain Diagnostic Associates, Niagara, Wisconsin. *Medical Director, ${ }^{* *}$ statistician, ${ }^{\#}$ clinical coordina-

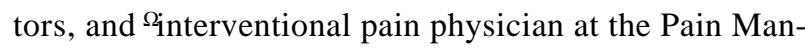
agement Center of Paducah. \#Medical Director at Pain Diagnostic Associates. Address correspondence: Laxmaiah Manchikanti, MD, 2831 Lone Oak Road, Paducah, Kentucky 42003. E-mail: drm@asipp.org
(3). Back pain is prevalent in $12 \%$ of children and adolescents, $15 \%$ of adults, and $27 \%$ of the elderly (1). The prevalence of chronic, persistent low back pain at 12 months is shown to be $28 \%$ to $75 \%$, in contrast to the earlier reports of $10 \%(1,4)$.

Discography, discogenic pain and epidural steroid injections are the most contentious and misunderstood interventional techniques (4-19). Since the introduction of epidural injections in the early 1900s, numerous publications have appeared in support of and some in opposition to epidural injections in managing low back pain or lower extremity pain. Along with these reports, numerous systematic reviews of the effectiveness of epidural steroid injections have also appeared, with conflicting opinions $(4,16-19)$. The reports of overall effectiveness of epidural steroid injections have been highly variable. 
Tissues in the low back capable of transmitting pain include muscles, ligaments, fascia, discs, nerve root dura, and facet joints (20). It is difficult to identify the causative factor for low back pain which may be either a facet joint or disc or another structure, which, generally, is differentiated based on clinical features of somatic/referred pain or radicular pain (4). Chronic low back pain is a diagnostic dilemma in $85 \%$ of patients, even in experienced hands with all of the available technology (4). Considering the above factors, it is logical to assume that, in some cases, epidural steroids were not indicated or delivery of steroids was not target specific. In addition, it is believed that the benefits of epidural steroid injections may be multi-fold. The explanations are based in part on the pharmacological and physical actions of local anesthetics, corticosteroids, and other agents, as well as physical effects, including clearing of the adhesions or inflammation from the vicinity of the nerve root sleeve (4), and neurolytic or other unknown effects (21).

Epidural steroid injections are indicated in patients failing to respond to less conservative modalities of treatments, with physical therapy, exercises and drug therapy. However, it has been stated that epidural steroid injections work best with a radicular component with little low back pain. Theoretically, epidural steroids should be effective in discogenic pain or in patients with nerve root or dural irritation. But their effectiveness has been reported in low back pain without disc herniation.

There is extensive literature available on epidural steroid injections in general and caudal epidural injections in particular, with multiple randomized and prospective trials. However, there are no reports in the literature describing the effectiveness of epidural injections in patients with low back pain, based on results of provocative discography. Discography is considered as a physiological test that explicitly determines whether a disc is painful or not, and the specificity of discography was clearly established (12). Discogenic pain was reported to be present in $26 \%$ of the patients in one study (5), whereas it had been reported to be present in $39 \%$ of the patients in a previous study (6). Manchikanti et al (5) also reported segmental dural or nerve root pain in $13 \%$ of the patients who responded to transforaminal epidural steroid injections. The role of the dorsal root ganglion in causation of low back pain is increasingly recognized (22-26). Chemical stimuli in a degenerative disc have been reported to play a substantial role as well. In this context, the observations of the effects of high phospholipase $\mathrm{A}_{2}$ enzyme activity, and a wide variety of other substances, with the ability to excite - or increase the excitability of - primary sensory neurons, including prostaglandin, histamine-like substances, potassium ions, lactic acid, and several polypeptides, is becoming exceedingly important (26-36). Weinstein et al (3740) emphasized the important role of the dorsal root ganglion, which is located in the intervertebral foramen and serves as a warehouse for all kinds of peptides. It is very likely that the dorsal root ganglion has a pain-modulating function around each motion segment. It has also been described that since the dorsal root ganglion and spinal nerve are embedded in extraforaminal fat and connective tissue beneath the intertransverse membrane, and the posterior primary ramus of the spinal nerve passes through the medial aspect of the membrane before distributing its branches to the dorsal musculature, any stress to the intertransverse membrane may also irritate the dorsal root ganglion, due to the interconnections through connective tissue and fat (41). In addition, this irritation may be facilitated through instability and loading. Manchikanti et al (5) showed in an evaluation of the relative contribution of various structures in chronic low back pain, $40 \%$ of patients with facet joint pain, $26 \%$ with discogenic pain, and $2 \%$ with sacroiliac joint pain; hence, $32 \%$ of the patients were without a diagnosis. A large number of these patients $(32 \%)$ may respond to epidural steroid injections. Similarly, patients who have been judged to have discogenic pain $(26 \%)$ also may respond to epidural steroid injections. Thus, all the patients who are negative for facet joint or sacroiliac joint pain may be considered as candidates for epidural steroid injections. While patients with positive provocative discography may be candidates for intradiscal electrothermal annuloplasty or percutaneous disc decompression in some cases, the procedures are not feasible secondary to multiple reasons in a significant number of these patients.

Hence, this study was undertaken to evaluate the role of caudal epidural steroid injections in patients with positive or negative provocative discography. The issues explored included duration of relief with caudal epidural injections, in a prospective study evaluating significant pain relief, overall health status, drug intake, and return-to-work status.

\section{METHODS}

One hundred consecutive patients without evidence of disc herniation or radiculitis, who had failed to respond to conservative management which included some or all of the modalities with drug therapy, chiropractic, physical therapy and exercises, underwent discography utilizing strict cri- 
teria of concordant pain and negative adjacent discs, after being judged to be negative for facet joint and/or sacroiliac joint pain utilizing comparative local anesthetic blocks. Provocative discography was carried out at the suspected levels in all 100 patients after they had undergone comparative local anesthetic blocks for facet joint and/or sacroiliac joint pain. The diagnostic criteria adapted included that, for a disc to be deemed the source of pain, provocation of that disc should reproduce the patient's usual and customary pain; and that an adjacent disc should be negative (13). Any other response was considered negative. Of these 100 patients, 62 patients also underwent caudal epidural steroid injections with Sarapin ${ }^{\circledR}$. All the patients undergoing caudal epidural steroids with Sarapin were included in this study. All the patients consented to participate. Of the 62 patients included in the study, 45 of the 55 patients comprising patients negative on provocative discography were included in Group I; whereas in Group II, 17 of 45 patients with positive provocative discography were included. The remaining patients either underwent other treatments, including intradiscal electrothermal annuloplasty or percutaneous disc decompression with nucleotomy, or did not undergo further interventions. There were 10 patients in Group I and 6 patients in Group II who did not undergo any interventions.

Patients younger than 20 years of age and older than 80 years were included in the study. The evaluation included data collection as to the variables of age, gender, duration of pain in months, nature of onset, height, weight, and history of previous surgical interventions; the number of injections received; the quality and duration of pain relief; overall health status; psychological status; narcotic intake; and employment and work status in pre- and post-treatment periods. The quality of pain relief was characterized as less than $50 \%$ relief, or greater than $50 \%$ relief. Pain relief greater than $50 \%$ was considered significant, and these patients were characterized as successful with significant pain relief.

All procedures were performed by one physician in an ambulatory surgery setting, either in a sterile operating room or in a treatment room. All caudal epidural injections were performed under fluoroscopy, with patients in the prone position, under appropriate monitoring with intravenous (IV) access and sedation with midazolam and fentanyl. With sterile preparation, access to the epidural space was obtained, which was confirmed by injection of nonionic contrast. Following this, based on each patient's contrast flow and distribution, $6 \mathrm{~mL}$ to $20 \mathrm{~mL}$ mixture was injected, consisting of lidocaine hydrochloride
(Xylocaine ${ }^{\circledR}$ ) and Sarapin ${ }^{\circledR}$, with $6 \mathrm{mg}$ of betamethasone or $40 \mathrm{mg}$ of methylprednisolone.

Following the blocks, the patients were discharged home. Upon a return visit, each patient was evaluated for amount of pain relief on the basis of a numeric pain-rating scale, and perceived physical health, perceived mental health, and perceived functional status by the patient and physician. Patients were also evaluated at each visit as to narcotic intake. All features were evaluated at each visit by a treating physician and at the end of treatment by a physician not involved in treatment, and the data were tabulated. Any potential complications were also evaluated at each visit.

Pain was assessed by a 10-point numeric pain-rating scale. Average pain, physical health, mental health, and functional status were determined from multiple sources, including patient description of the pain; and patient perception of physical health, mental health and functional status; as well as evaluations performed with psychological evaluation and evaluation of ability to function and carry on important activities the patient was unable to perform prior to the intervention. Psychological status was determined by a psychological questionnaire, as well as psychological evaluation utilizing the Millon Clinical Multiaxial Inventory and/or Pain Patient Profile (P3). Narcotic intake was determined as none, mild, moderate, on heavy based on the dosage, frequency and class of drug. Intake of class IV narcotics, ie, propoxyphene napsylate (Darvocet $\left.{ }^{\circledR}\right)$, pentazocine hydrochloride (Talwin $\left.{ }^{\circledR}\right)$, on tramadol hydrochloride (Ultram $®$ ), up to a maximum of four times, or hydrocodone twice or less per day, was considered as mild; intake of class III narcotics, ie, hydrocodone, up to four times, as moderate; and intake of class II narcotics, ie, oxycodone, morphine, meperidine, transdermal fentanyl, on methadone in any dosage was considered as heavy. Employment and work status, classified as employed, unemployed, housewife, disabled, and retired, were also determined from the pretreatment and post-treatment work status. Patients were also judged to be successful or failed based on response to epidural steroid injections. Response of 1 week or greater with first injection, 2 weeks or greater with second injection, 4 weeks or greater with third injection, and total response of at least 6 weeks or greater was considered "successful." The data were evaluated and confirmed by one of the two physicians who were not performing the blocks and treating the patients.

Data were recorded on a database using Microsoft ${ }^{\circledR}$ Access $®$; the SPSS Version 9.0 statistical package was used to generate frequency tables, and the chi-squared statistic 
Table 1. Patient characteristics

\begin{tabular}{|c|c|c|c|}
\hline \multicolumn{2}{|l|}{ Number of patients } & \multirow{2}{*}{$\begin{array}{c}\text { Group I } \\
\text { Negative Discography } \\
\mathrm{N}=45\end{array}$} & \multirow{2}{*}{$\begin{array}{c}\text { Group II } \\
\text { Positive Discography } \\
\mathrm{N}=17\end{array}$} \\
\hline \multirow{3}{*}{ Gender } & & & \\
\hline & Men & $29 \%(13)$ & $29 \%(5)$ \\
\hline & Women & $71 \%(32)$ & $71 \%(12)$ \\
\hline \multirow{2}{*}{ Age (yrs.) } & Range & $23-64$ & $24-56$ \\
\hline & Mean \pm SEM & $40.5 \pm 1.43$ & $39.1 \pm 2.44$ \\
\hline \multirow{2}{*}{ Weight (lbs.) } & Range & $103-300$ & $120-320$ \\
\hline & Mean \pm SEM & $174 \pm 7.11$ & $171 \pm 8.18$ \\
\hline \multirow{2}{*}{ Height (inches) } & Range & $59-72$ & $61-72$ \\
\hline & Mean \pm SEM & $65.9 \pm 0.49$ & $66.0 \pm 0.76$ \\
\hline \multirow[t]{2}{*}{ Mode of onset of pain } & $\begin{array}{l}\text { Following an } \\
\text { incident }\end{array}$ & $62 \%(28)$ & $88 \%(15)$ \\
\hline & Gradual onset & $38 \% *(17)$ & $12 \%(2)$ \\
\hline \multirow[t]{2}{*}{ Duration of pain (years) } & Range & $0.5-32$ & $0.5-12$ \\
\hline & Mean \pm SEM & $7.7 \pm 3.94$ & $4.0 \pm 3.1$ \\
\hline Post-surgical & & $20 \%(9)$ & $18 \%(3)$ \\
\hline
\end{tabular}

was used to test the significant difference between groups.

RESULTS

Fisher's Exact Test was used wherever expected value was less than five. Student's t-test was used to test mean difference between groups. Results were considered statistically significant if the $p$-value was less than 0.05 .

\section{Patient Characteristics}

Demographic data are shown in Table 1, with no signifi-

Table 2. Details of multiple procedures over a period of 2 years

\begin{tabular}{lcccc}
\hline Procedures & \multicolumn{1}{c}{ Group I } & \multicolumn{2}{c}{ Group II } \\
& Negative Discography & \multicolumn{2}{c}{ Positive Discography } \\
\hline Number & $\%$ & Number & 100 \\
Two & 45 & 100 & 17 & 71 \\
Three & 33 & 73 & 12 & 53 \\
Four & 25 & 56 & 9 & 47 \\
Five & 24 & 53 & 8 & 35 \\
Six & 19 & 42 & 6 & 24 \\
Seven & 12 & 27 & 4 & 18 \\
Eight & 11 & 24 & 3 & 12 \\
Nine & 6 & 13 & 2 & 12 \\
Ten & 2 & 4 & 2 & 6 \\
\hline
\end{tabular}


Table 3. Proportion of failed and successful patients with epidural steroids

\begin{tabular}{lcc}
\hline & $\begin{array}{c}\text { Group I } \\
\text { Negative } \\
\text { Discography }\end{array}$ & $\begin{array}{c}\text { Group II } \\
\text { Positive } \\
\text { Discography }\end{array}$ \\
\hline Failed & $31 \%(14)$ & $35 \%(6)$ \\
Successful & $69 \%(31)$ & $65 \%(11)$ \\
\hline
\end{tabular}

cant differences noted between groups in terms of age, gender, weight, height, duration of pain, and history of previous surgical intervention. However, a greater proportion of patients in Group I presented with pain of gradual onset.

\section{Injection Characteristics}

Table 2 illustrates the details of patients undergoing multiple procedures over a period of 2 years. Only $56 \%$ of patients in Group I and 53\% in Group II underwent three procedures.

Table 3 shows the proportion of patients in failed and successful categories in both groups.

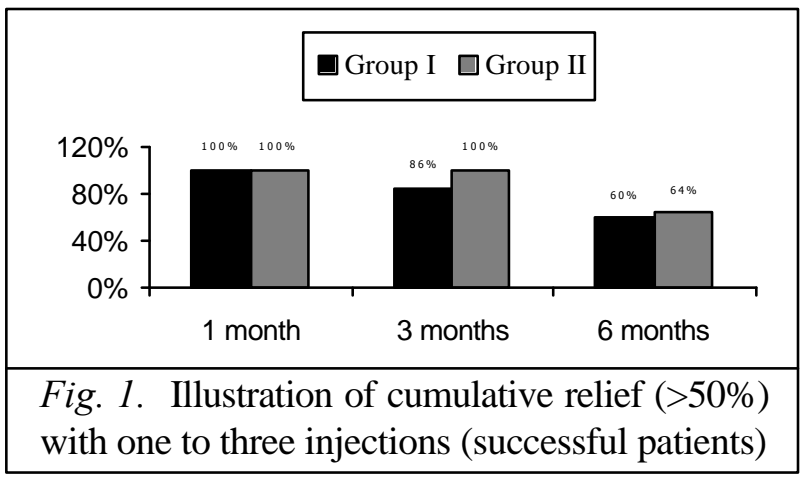

\section{Pain Relief}

Table 4 shows significant relief with each injection. There was significant difference noted among groups with injections five to eight with better response in Group I. Relief ranged from 0 to 73 weeks, with mean relief ranging from 5.0 weeks to 13.3 weeks. Average relief for all patients and all injections was 10.2 weeks in Group I, and 9.3 weeks in Group II.

Fig. 1 illustrates cumulative relief $(>50 \%)$ with one to three injections; $100 \%$ of the patients experienced relief lasting 1 month in both groups, which declined to $86 \%$ in Group II at 3 months, and to $60 \%$ in Group I and $64 \%$ in Group II

Table 4. Comparison of significant relief (>50\%) with each injection by group in weeks, in successful category

\begin{tabular}{|c|c|c|c|c|}
\hline \multirow[t]{2}{*}{$\begin{array}{l}\text { Injection } \\
\text { Number }\end{array}$} & \multicolumn{2}{|c|}{$\begin{array}{c}\text { Group I } \\
\text { Negative Discography }\end{array}$} & \multicolumn{2}{|c|}{$\begin{array}{c}\text { Group II } \\
\text { Positive Discography }\end{array}$} \\
\hline & Mean \pm SEM & Range & Mean \pm SEM & Range \\
\hline One & $8.5 \pm 0.43(31)$ & $4-13$ & $13.3 \pm 6.03$ & $3-73$ \\
\hline Two & $8.7 \pm 0.51(31)$ & $3-13$ & $8.7 \pm 1.02(10)$ & $4-13$ \\
\hline Three & $9.8 \pm 0.51(25)$ & $4-13$ & $9.5 \pm 1.20(8)$ & $4-13$ \\
\hline Four & $12.4 \pm 1.80(24)$ & $4-13$ & $9.4 \pm 1.51(8)$ & $0-13$ \\
\hline Five & $11.3^{*} \pm 0.41(19)$ & $9-13$ & $8.7 \pm 1.67(6)$ & $1-13$ \\
\hline Six & $10.7^{*} \pm 0.48(12)$ & $9-13$ & $5.0 \pm 2.92$ & $0-11$ \\
\hline Seven & $12.1^{*} \pm 0.49$ & $9-13$ & $6.0 \pm 3.00(3)$ & $0-9$ \\
\hline Eight & $11.8^{*} \pm 0.65(6)$ & $9-13$ & $7.5 \pm 1.5(2)$ & $6-9$ \\
\hline Nine & $11.0 \pm 2.00$ & $9-13$ & $5.5 \pm 3.50(2)$ & $2-9$ \\
\hline Ten & - & - & $9(1)$ & 9 \\
\hline Average & $10.2 \pm 0.33$ & $3-13$ & $9.3 \pm 1.28$ & $0-73$ \\
\hline
\end{tabular}




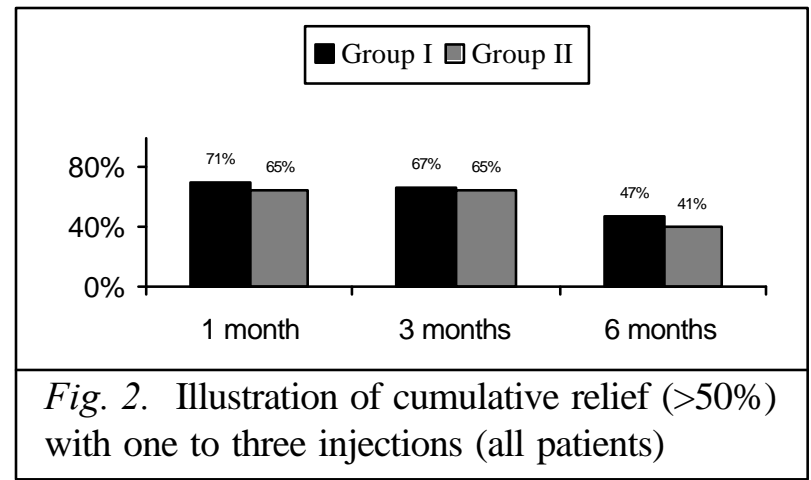

at 6 months. Fig. 2, illustrates the analysis, which included all patients (62), with relief shown in $71 \%$ and $65 \%$ at 1 month, in $67 \%$ and $65 \%$ at 3 months, and in $47 \%$ and $41 \%$ at 6 months in Group I and Group II, respectively.

\section{Overall Health Status}

Table 5 shows significant overall improvement in health status, with improvement in both treatment groups in the successful category compared to the failed category.

\section{Psychological Status}

Psychological status evaluation (Table 6) showed significant improvement in success in all categories.

\section{Narcotic Intake}

Table 7 illustrates narcotic intake and changes in both groups in both categories. The successful group showed reduction in narcotic intake, with heavy intake.

\section{Employment Status}

Employment or work status is shown in Table 8. Patients who were employed and unemployed were considered as candidates for future employment or continued employment. Housewives, disabled patients, and patients over 65 who were retired were considered ineligible for future employment. A total of 11 patients from the successful category became employed during the treatment period and continued to be employed at the end of the treatment period. The increase in employment and reduction in unemployment were significant in the successful treatment group.

\section{Complications}

None of the various types of complications, including infection, rash, reaction to drugs, epidural or subarachnoid blockade, postlumbar puncture headache, and/or weight gain, were observed in any of the patients.

\section{DISCUSSION}

The effects of caudal epidural steroid injections were first reported by Goebert and colleagues (42). Since then, numerous reports have been published on the effectiveness of epidural steroids (21, 43-53). Bogduk and Govind (54) described that, virtually, the only indication for epidural steroids on which the literature is unanimously agreed is lumbar radicular pain. It may be contentious how reliable and valid that symptom was in the past, and how reliable and valid was identification by investigators who reported the efficacy of epidural steroids; but, nonetheless, "sciatica" pain is the leading, if not sole, indication (54). In that regard, Bogduk et al (17) recommended that epidural steroids be used only for lumbar radicular pain; and that the use of epidural steroids for back pain has to be considered experimental. The literature also suggested that effectiveness of epidural steroids was greater in patients with a shorter history, and in patients with pain in the lower limb but with minimal or no neurological signs.

Table 5. Comparison of overall health status pre- and post-treatment in successful and failed categories in both groups combined

\begin{tabular}{lcccc} 
& \multicolumn{2}{c}{ Failed (20) } & \multicolumn{2}{c}{ Successful (42) } \\
\cline { 2 - 5 } & Pre & Post & Pre & Post \\
\hline Average pain & $7.7 \pm 0.15$ & $6.4^{*} \pm 0.33$ & $7.7 \pm 0.14$ & $3.6^{*} \# \pm 0.21$ \\
Physical health & $5.9^{\circledR} \pm 0.26$ & $6.3^{*} \pm 0.22$ & $4.9 \pm 0.20$ & $7.1^{*} \# \pm 0.17$ \\
Mental health & $4.5 \pm 0.27$ & $5.5^{*} \pm 0.27$ & $4.5 \pm 0.21$ & $6.8^{*} \# \pm 0.20$ \\
Functional status & $3.9 \pm 0.19$ & $4.4^{*} \pm 0.14$ & $3.5 \pm 0.17$ & $5.6^{*} \# \pm 0.15$ \\
\hline
\end{tabular}

* Indicates significant difference between pre- and post-treatment values ${ }^{\circledR}$ Indicates significant difference between failed and successful patients of pretreatment values \# Indicates significant difference between failed and successful patients of posttreatment values 
Table 6. Psychological status of the patients pre- and post-treatment in successful and failed categories in both groups combined

\begin{tabular}{lcccc}
\hline & \multicolumn{2}{c}{ Failed (20) } & \multicolumn{2}{c}{ Successful (42) } \\
\cline { 2 - 5 } & Pre & Post & Pre & Post \\
\hline Depression & $65 \%(13)$ & $60 \%(12)$ & $76 \%(31)$ & $48 \% *(20)$ \\
Generalized anxiety disorder & $70 \%(14)$ & $65 \%(13)$ & $78 \%(32)$ & $48 \% *(20)$ \\
Somatoform disorder or Somatization & $65 \%(13)$ & $65 \% \#(13)$ & $73 \%(30)$ & $33 \% *(14)$ \\
Symptom magnification & $40 \%(8)$ & $40 \%(8)$ & $56 \%(23)$ & $26 \% *(11)$ \\
\hline
\end{tabular}

* Indicates significant difference between pre- and post-treatment values \# Indicates significant difference between failed and successful patients of post-treatment values

Because corticosteroids have anti-inflammatory properties, the rationale for using epidural steroids has been that they relieve radicular pain by exerting an anti-inflammatory effect on nerve roots inflamed by contact with prolapsed disc materials (17). Although, this rationale has been supported in animal experiments and by circumstantial clinical evidence, the demonstration of inflammation before treatment has never been an indication, largely because there is no simple way of detecting it. In addition, steroids also have been shown to exert a reversible local anesthetic effect on nerves. Modern evidence has implicated intervertebral disc herniation in only a small percentage of low back pain $(7,55)$.

Thus, the theoretical consideration that a simple compression or mass effect is the mechanism of pain due to disc disease has been questioned. Multiple studies also evaluating the progress of disc herniations have shown that, even though resolution of symptoms tends to be associated with dimunition of the size of disc herniations, it is not always the case, as compression may continue in spite of resolu- tion of the symptomatology. It also has been shown that disc herniations that are evident on computerized tomographic axial scan or on magnetic resonance imaging scan can also be asymptomatic. In fact, Mixter and Ayers (56) in 1935, soon after the hallmark description of Mixter and Barr (57) in 1934, demonstrated that radicular pain can occur without disc herniation. Thus, mechanisms proposed to explain radicular pain include not only partial axonal damage, neuroma formation, focal demyelination, intraneural edema, and impaired microcirculation $(22,58)$; but also chemical irritation and inflammation around the discs and nerve roots, which is considered a pain generator with or without mechanical factors $(23,24,27-36)$. However, some studies have questioned the inflammatory hypothesis (59-61). Internal disc disruption and annular rupture also have been shown to be responsible for low back and lower extremity pain (62-67).

Evidence in support of the anti-inflammatory hypothesis of steroids includes (1) reduction of the nerve root injury produced by placement of nucleus pulposus in the epidu-

Table 7. Comparison of narcotic intake in pre- and post-treatment periods, in successful and failed categories in both groups combined

\begin{tabular}{lcccc}
\hline & \multicolumn{2}{c}{ Failed (20) } & \multicolumn{2}{c}{ Successful (42) } \\
\cline { 2 - 5 } & Pre & Post & Pre & Post \\
\hline None & $5 \%(1)$ & $5 \%(1)$ & $0 \%$ & $5 \%(2)$ \\
Mild & $20 \%(4)$ & $20 \%(4)$ & $12 \%(5)$ & $26 \%(11)$ \\
Moderate & $20 \%(4)$ & $25 \%(5)$ & $36 \%(15)$ & $45 \%(19)$ \\
Heavy & $55 \%(11)$ & $50 \%(10)$ & $52 \%(22)$ & $24 \% * \#(10)$ \\
\hline
\end{tabular}

* Indicates significant difference between pre- and post-treatment values \# Indicates significant difference between failed and successful patients of post-treatment values 
Table 8. Employment status of the patients pre-and post-treatment in successful and failed categories in both groups combined

\begin{tabular}{lcccc}
\hline & \multicolumn{2}{c}{ Failed (20) } & \multicolumn{2}{c}{ Successful (42) } \\
\cline { 2 - 5 } & Pre & Post & Pre & Post \\
\hline Employed & $30 \%(6)$ & $30 \%(6)$ & $24 \%(10)$ & $50 \% * \#(21)$ \\
Unemployed & $45 \%(9)$ & $40 \%(8)$ & $31 \%(13)$ & $7 \%(3)$ \\
Housewife & $5 \%(1)$ & $5 \%(1)$ & $2 \%(1)$ & $2 \%(1)$ \\
Disabled & $20 \%(4)$ & $25 \%(5)$ & $43 \%(18)$ & $40 \%(17)$ \\
* Indicates significant difference between pre- and post-treatment values \# Indicates significant difference between failed and success- \\
ful patients of post-treatment values
\end{tabular}

ral space, by IV methylprednisolone (68); (2) a significant effect on thermal hyperalgesia by epidural injection of betamethasone in a model of lumbar radiculopathy (69); (3) the effects of steroid on spontaneous resorption of herniated intervertebral discs in an experimental study (70); (4) a steady reduction in phospholipase $\mathrm{A}_{2}$ activity in an animal model of radiculopathy with steroids (71); (5) prevention of development of autonomy and neuropathic edema with methylprednisolone (72); and (6) reduction of increased vascular permeability in spinal nerve roots, induced by epidural nucleus pulposus application by methylprednisolone (73).

The rationale for steroid usage in neural blockade is primarily based on the benefits of neural blockade, including pain relief which outlasts by hours, days, and sometimes weeks, the transient pharmacologic action of other adjuvant agents such as local anesthetics and others. While there are no clear-cut explanations for these benefits available currently, it is believed that neural blockade alters or interrupts nociceptive input, reflex mechanism of the afferent limb, self-sustaining activity of the neuron pools and neuraxis, and the pattern of central neuronal activities (74). Corticosteroids reduce inflammation either by inhibiting the synthesis or release of a number of proinflammatory substances. Various modes of action of corticosteroids include membrane stabilization; inhibition of neural peptide synthesis or action; blockade of phospholipase $\mathrm{A}_{2}$ activity; prolonged suppression of ongoing neuronal discharge; suppression of sensitization of dorsal horn neurons; and reversible local anesthetic affect. Other explanations may include alteration or interruption of the nociceptive input, reflected mechanism of the afferent limb, self-sustaining activity of the neuron pools and neuraxis, and the pattern of central neuronal activities.
Physical effects of injecting high-volume solutions into the epidural space may cause adhesiolysis. Beneficial actions may be explained on the basis of Sarapin, which is a suspension of powdered Sarracenia purpurin (pitcher plant) in alkaline solution. The value of Sarapin in relieving pain of neurologic origin was reported by Bates and Judovich in $1931(75,76)$. However, clinical investigation of Sarapin for epidural administration is limited to only one study (21). Sarapin has been reported to cause no motor weakness following injection of the peripheral nerve; it also does not cause or affect loss of touch, pressure, pinprick, or temperature sensibility; and it has an excellent risk/benefit ratio. Controlled studies with procaine, saline, and water show prolonged duration of effect in favor of the pitcherplant preparation (76). The basis of the pitcher plant derivative, or Sarapin, was explained by experiments performed on the action potentials of the saphenous nerve of the cat, which showed that the $\mathrm{C}$-fiber potential was completely obliterated by pitcher-plant extract after immersion in the solution for about 5 minutes. Researchers theorize that the distillate contains an unidentified biological substance that potentiates the action of the ammonium ion. Modest but significant benefits were demonstrated with diagnostic and therapeutic facet joint nerve blocks utilizing Sarapin $(77,78)$. Thus, the effects observed in this study may be due to any of the above mechanisms or an unknown mechanism affecting the pain generators thus far not identified, namely the disc. However, this may include its effects on the dorsal root ganglion, ligaments, musculature, and other structures in the intervertebral foramen.

Rhyne et al (79) described discogenic back pain as a syndrome of nonradicular pain in the absence of spinal deformity, instability, and neural tension signs. However, the diagnosis of discogenic back pain is confirmed by pro- 
vocative discography. The natural history of discogenic pain is not known. The pain is thought to be modulated via nociceptive fibers through the sinuvertebral nerve, which is stimulated by tears in the posterior longitudinal ligament and the annulus fibrosis. Discography has been used extensively in determining the anatomic segment thought to be responsible for the patient's pain. Various surgical treatments reported include percutaneous discectomy, discectomy, interbody fusion, posterolateral fusion, and posterior lumbar interbody fusion, with success rates ranging from $30 \%$ to $96 \%$. Intradiscal electrothermal therapy also has been reported, with success rates in the range of $60 \%$ to $70 \%$ (4). Rhyne et al (79) evaluated the outcome of an operated discogram positive for low back pain. They reported that $68 \%$ of the patients improved, $8 \%$ stayed the same, and $24 \%$ worsened. They reported no correlation between disc level, gender, smoking and outcome. They concluded that discogenic low back pain improved in patients without psychiatric disease, without surgery. Thus, epidural steroid injections appear to be a reasonable alternative to manage discogram-positive chronic low back pain if the patients continue to suffer with pain. However, intradiscal electrothermal therapy in suitable candidates may yield better results. There are no descriptions, however, of management of discogram-negative chronic low back pain in patients who are also negative for facet joint pain, as well as sacroiliac joint pain. Apparently, these patients are suffering with pain which is not diagnosable by present technology and precision diagnostic injections.

The current study is the first prospective study to have treated the patients, without facet joint pain or sacroiliac joint pain, under fluoroscopy utilization, evaluating the effectiveness of caudal epidural steroids in patients with positive and negative provocative discography. In this study, both groups of patients, those positive or negative for concordant pain for provocative discography, showed significant improvement in all parameters. However, the results of this study should be viewed only as preliminary. Further research should be conducted to confirm or disprove these findings. This publication may serve as a platform for future research.

\section{CONCLUSION}

Caudal epidural injections are an effective modality of treatment in managing chronic low back pain after exclusion of facet joint pain and sacroiliac joint pain in patients either positive or negative for provocative discography. Caudal epidural injections with steroids and Sarapin are effective in providing significant pain relief, improvement in functional status, improvement in overall psychological status, and return to work.

\section{ACKNOWLEDGMENTS}

We would like to thank Marla K. Neihoff and Lori A. Rose, medical records coordinators, for their assistance in collection of data. We would also like to thank Denise Pratt and Tonie Hatton, transcriptionists, for their assistance with transcription of the manuscript.

\section{REFERENCES}

1. Manchikanti L. Epidemiology of low back pain. Pain Physician 2000; 3:167-192.

2. Lawrence RC, Helmick CG, Arnett FC. Estimates of the prevalence of arthritis and selected musculoskeletal disorders in the United States. Arthritis \& Rheumatism 1998; 41:778-799.

3. Cassidy D, Carroll L, Cote P. The Saskatchewan Health and Back Pain Survey. The prevalence of low back pain and related disability in Saskatchewan adults. Spine 1998; 23:1860-1867.

4. Manchikanti L, Singh V, Kloth Det al. Interventional techniques in the management of chronic pain. Part 2.0. Pain Physician 2001; 4:24-96.

5. Manchikanti L, Singh V, Pampati V et al. Evaluation of the relative contributions of various structures in chronic low back pain. Pain Physician 2001;4:308316.

6. Schwarzer AC, Aprill CN, Derby R et al. The prevalence and clinical features of internal disc disruption in patients with chronic low back pain. Spine 1995; 20:1878-1883.

7. Sehgal N, Fortin JD. Internal disc disruption and low back pain. Pain Physician 2000; 3:143-157.

8. Guyer RD, Ohnmeiss DD. Contemporary concepts in spine care. Lumbar discography. Position statement from the North American Spine Society and Therapeutic Committee. Spine 1995; 18:2048-2059.

9. Carragee EJ, Tanner CM, Yang B et al. False-positive findings on lumbar discography. Spine 1999;24:25422547.

10. Carragee E, Tanner C, Khurana S et al. The rates of false-positive lumbar discography in select patients without low back symptoms. Spine 2000; 25:13731381.

11. Manchikanti L, Singh VS, Pampati VS et al. Provocative discography in low back pain patients with or without somatization disorder: A randomized, prospective evaluation. Pain Physician 2001; 4:227-239.

12. Walsh TR, Weinstein JN, Spratt KP et al. Lumbar discography in normal subjects. J Bone Joint Surg 1990; 72A:1081-1088. 
13. Merskey H, Bogduk N (eds). Classification of chronic pain. Descriptions of Chronic Pain Syndromes and Definitions of Pain Terms, ed. 2, IASP Press, Seattle, 1994.

14. Nachemson AL, Vingard E. Assessment of patients with neck and back pain: A best-evidence synthesis. In Nachemson AL, Johnsson E (eds). Neck and Back Pain: The Scientific Evidence of Causes, Diagnosis, and Treatment. Lippincott, Williams \& Wilkins, Philadelphia, 2000; pp 189-235.

15. Ramsey SD, Luce BR, Deyo R et al. The limited state of technology assessment for medical devises: Facing the issues. Am J Managed Care 1998;4:188-199.

16. Koes BW, Scholten RJPM, Mens JMA et al. Efficacy of epidural steroid injections for low back pain and sciatica: A systematic review of randomized clinical trials. Pain 1995; 63:279-288.

17. Bogduk N, Christophidis N, Cherry D et al. Epidural use of steroids in the management of back pain. $\mathrm{Re}$ port of working party on epidural use of steroids in the management of back pain. National Health and Medical Research Council. Canberra, Commonwealth of Australia, 1994, pp 1-76.

18. Watts RW, Silagy CA. A meta-analysis on the efficacy of epidural corticosteroids in the treatment of sciatica. Anaesth Intens Care 1995; 23:564-569.

19. Mugford HK. Conflicting conclusions from two systematic reviews of epidural steroid injections for sciatica: Which evidence should general practitioners heed? Br J Gen Pract 1999; 49:57-61.

20. Kuslich SD, Ulstrom CL, Michael CJ. The tissue origin of low back pain and sciatica: A report of pain response to tissue stimulation during operation on the lumbar spine using local anesthesia. Orthop Clin North Am 1991;22:181-187.

21. Manchikanti L, Pampati V, Rivera J et al. Caudal epidural injections with Sarapin or steroids in chronic low back pain. Pain Physician 2001;4:322-335.

22. Devor M. Pain arising from the nerve root and the dorsal root ganglia and chronically injured axons: A physiological basis for the radicular pain of nerve root compression. Pain 1977; 3:25-41.

23. Yabuki S, Kikuchi S, Olmarker K et al. Acute effects of nucleus pulposus on blood flow and endoneurial fluid pressure in rat dorsal root ganglia. Spine 1998; 23:2517-2523.

24. Yabuki S, Igarashi T, Kikuchi S. Application of nucleus pulposus to the nerve root simultaneously reduces blood flow in dorsal root ganglion and corresponding hindpaw in the rat. Spine 2000; 25:1471-1476.

25. Harrington JF, Messier AA, Bereiter D et al. Herniated lumbar disc material as a source of free glutamate available to affect pain signals through the dorsal root ganglion. Spine 2000; 25:929-936.

26. Coppes MH, Marani E, Thomeer RT et al. Innervation of "painful" lumbar discs. Spine 1997; 22:2342-
2350.

27. McCarron RF, Wimpee MW, Hudkins PG et al. The inflammatory effects of nucleus pulposus: A possible element in the pathogenesis of low back pain. Spine 1987; 12:760-764.

28. Kayama S, Konno S, Olmarker K et al. Incision of the annulus fibrosus induces nerve root morphologic, vascular, and functional changes. Spine 1996;21:25392543.

29. Chaoyang C, Cavanaugh JM, Ozaktay C et al. Effects of phospholipase $\mathrm{A}_{2}$ on lumbar nerve root structure and function. Spine 1997;22:1057-1064.

30. Kawaguchi S, Yamashita T, Yokogushi K et al. Immunophenotypic analysis of the inflammatory infiltrates in herniated intervertebral discs. Spine 2001; 26:1209-1214.

31. Saal JS, Franson RC, Dobrow R et al. High levels of inflammatory phospholipase A2 activity in lumbar disc herniations. Spine 1990; 15:674-678.

32. Kanerva A, Kommonen B, Gronbald M et al. Inflammatory cells in experimental intervertebral disc injury. Spine 1997; 22:2711-2715.

33. Habtemariam A, Virri J, Grönblad M et al. The role of mast cells in disc herniation inflammation. Spine 1999; 24:1516-1520.

34. Ishikawa H, Nohara Y, Miyauti S. Action of chondroitinase $\mathrm{ABC}$ on epidurally transplanted nucleus pulposus in the rabbit. Spine 1999;24:1071-1076.

35. Cooper RG, Freemont AJ, Hoyland JA et al. Herniated interventional disc-associated periradicular fibrosis and vascular abnormalities occur without inflammatory cell infiltration. Spine 1995; 20:591-598.

36. Olmarker K, Rydevik B. Selective inhibition of tumor necrosis factor- $\alpha$ prevents nucleus pulposus-induced thrombus formation, intraneural edema, and reduction of nerve conduction velocity. Spine 2001;26:863-869.

37. Weinstein JN, Claverie W, Gibson S. The pain of discography. Spine 1988; 13:1344-1348.

38. Weinstein JN. Mechanism of spinal pain: The dorsal root ganglion and its role as a mediator of low back pain. Spine 1986; 11:999-1001.

39. Weinstein JN. Perception of pain. In Kirkaldy W, (ed). Managing Low Back Pain. ed. 2. Edinburgh; Churchill Livingstone, 1988; pp. 83-92.

40. Weinstein JN. Neuropharmacologic effects of vibration on the dorsal root ganglion: An animal model. Spine 1988; 13:521-525.

41. Sizer PS Jr, Phelps V, Matthijs O. Pain generators of the lumbar spine. Pain Practice 2001;1:255-273.

42. Goebert HW, Jallo SJ, Gardner WJ et al. Painful radiculopathy treated with epidural injections of procaine and hydrocortisone acetate results in 113 patients. Anesth Analg 1961; 140:130-134.

43. Manchikanti L, Pakanati RR, Pampati V. Comparison of three routes of epidural steroid injections in low back pain. Pain Digest 1999; 9:277-285. 
44. Breivik H, Hesla PE, Molnar I et al. Treatment of chronic low back pain and sciatica. Comparison of caudal epidural injections of bupivacaine and methylprednisolone with bupivacaine followed by saline. In Bonica JJ, Albe-Fesard D (eds). Advances in Pain Research and Therapy. Raven Press, New York, 1976, Vol. 1, pp 927-932.

45. Bush K, Hillier S. A controlled study of caudal epidural injections of triamcinolone plus procaine for the management of intractable sciatica. Spine 1991; 16:572-575.

46. Matthews JA, Mills SB, Jenkins VM et al. Back pain and sciatica: Controlled trials of manipulation, traction, sclerosant and epidural injections. Brit $J$ Rheumatol 1987; 26:416-423.

47. Beliveau P. A comparison between epidural anesthesia with and without corticosteroids in the treatment of sciatica. Rheum Phys Med 1971; 11:40-43.

48. Czarski Z. Leczenie rwy kulszowej wstrzykiwaniem hydrokortyzonu inowokainy do rozworu kryzowego. Przeglad Kekarski 1965; 21:511-513.

49. Revel M, Auleley GR, Alaoui S et al. Forceful epidural injections for the treatment of lumbosciatic pain with post-operative lumbar spinal fibrosis. Rev Rhum Engl Ed 1996; 63:270-277.

50. Meadeb J, Rozenberg S, Duquesnoy B et al. Forceful sacrococcygeal injections in the treatment of postdiscectomy sciatica. A controlled study versus glucocorticoid injections. Joint Bone Spine 2001; 68:43-49.

51. Yates DW. A comparison of the types of epidural injection commonly used in the treatment of low back pain and sciatica. Rheum Rehab 1978; 17:181-186.

52. Waldman SD. The caudal epidural administration of steroids in combination with local anesthetics in the palliation of pain secondary to radiographically documented lumbarherniated disc: A prospective outcome study with 6-months follow-up. Pain Clin 1998; 11:4349.

53. Apathy, A, Penczner G, Licker E et al. Caudal epidural injection in the management of lumbosacral nerve pain syndromes. Orv Hetil 1999; 140:1055-1058.

54. Bogduk N, Govind J. Epidural steroids in medical management of acute lumbar radicular pain. ed 1. Cambridge Press, New Castle, 1999, pp 71-79.

55. Fortin JD. Precision diagnostic disc injections. Pain Physician 2000;3:271-288.

56. Mixter WJ, Ayers JB. Herniation or rupture of the intervertebral disc into the spinal canal. NEnglJMed 1935; 213:385-395.

57. Mixter WJ, Barr JS. Rupture of the intervertebral disc with involvement of the spinal canal. NEngl JMed 1934; 211:210-215.

58. Olmarker K, Rydevik B, Holm S. Edema formation in spinal nerve roots induced by experimental, graded compression: An experimental study on the pig cauda equina with special reference to differences in effects between rapid and slow onset of compression. Spine 1989; 14:569-573.

59. Rothoerl RD, Woertgen C, Holzschuh M et al. Is there a clinical correlate to the histologic evidence of inflammation in herniated lumbar disc tissue? Spine 1998; 23:1197-1201.

60. Grönblad M, Virri J, Seitsalo S et al. Inflammatory cells, motor weakness, and straight leg raising in transligamentous disc herniations. Spine 2000; 25:2803-2807.

61. Hoyland JA, Freemont AJ, Jayson MI. Intervertebral foramen venous obstruction. A cause of periradicular fibrosis? Spine 1989; 14:558-568.

62. Crock HV. Isolated lumbar disc resorption as a cause of nerve root canal stenosis. Clin Orthop 1976; 115:109-115.

63. Schellhas KP, Pollei SR, Gundry CR et al. Lumbar disc high-intensity zone. Correlation of magnetic resonance imaging and discography. Spine 1996;21:7986.

64. Ito M, Incorvaia KM, Shiwei FY et al. Predictive signs of discogenic lumbar pain on magnetic resonance imaging with discography correlation. Spine 1998; 23:1252-1260

65. Aprill C, Bogduk N. High intensity zone: A diagnostic sign of painful lumbar disc on magnetic resonance imaging. Br J Radiol 1992; 65:361-369.

66. Buirski G. Magnetic resonance signal patterns of lumbar discs in patients with low back pain. Spine 1992; 17:1199-1204

67. Moneta GB, Videman T, Kaivanto K et al. Reported pain during lumbar discography as a function of anular ruptures and disc degeneration: A reanalysis of 833 discograms. Spine 1994; 17:1968-1974.

68. Olmarker K, Byrod G, Cornefijord M et al. Effects of methylprednisolone on nucleus pulposus-induced nerve root injury. Spine 1994; 19:1803-1808.

69. Hayashi N, Weinstein JN, Meller ST et al. The effect of epidural injection of betamethasone or bupivacaine in a rat model of lumbar radiculopathy. Spine 1998; 23:877-885.

70. Minamide A, Tamaki T, Hashizume Het al. Effects of steroids and lipopolysaccharide on spontaneous resorption of herniated intervertebral discs. An experience study in the rabbit. Spine 1998;23:870-876.

71. Lee HM, Weinstein JN, Meller ST et al. The role of steroids and their effects on phospholipase $\mathrm{A}_{2}$. An animal model of radiculopathy. Spine 1998; 23:11911196.

72. Kingery WS, Castellote JM, Maze M. Methylprednisolone prevents the development of autotomy and neuropathic edema in rats, but has no effect on nociceptive thresholds. Pain 1999; 80:555-566.

73. Byrod G, Otani K, Brisby H et al. Methylprednisolone reduces the early vascular permeability increase 
in spinal nerve roots induced by epidural nucleus pulposus application. JOrthop Res 2000; 18:983-987.

74. Fox AJ, Melzack R. Transcutaneous electrical stimulation to acupuncture. Comparison of treatment of low back pain. Pain 1976; 2:141-148.

75. Bates W, Judovich BD. Intractable pain. Anesthesiology 1942; 3:663-672.

76. Judovich BD, Bates W. Painsyndromes. Treatment by paravertebral nerve block. Philadelphia, FA Davis, 1950, pp 242-249.

77. Manchikanti L, Pampati VS, Bakhit CE et al. The diagnostic validity and therapeutic value of lumbar facet joint nerve blocks with or without adjuvant agents. Cur Rev Pain 2000; 4:337-344.

78. Manchikanti L, Pampati V, Bakhit CE et al. Effectiveness of lumbar facet joint nerve blocks in chronic low back pain: A randomized clinical trial. Pain Physician 2001; 4:101-117.

79. Rhyne AL, Smith SE, Wood KE et al. Outcome of unoperated discogram-positive low back pain. Spine 1995; 20:1997-2001. 